\title{
THE STUDY OF LOW-LACTOSE MILK WHEY STRUCTURE AND MODEL SYSTEMS ON ITS BASIS
}

\author{
Victoriya Gnitsevych ${ }^{1}$ \\ flamber1965@gmail.com \\ Tatiana Yudina \\ yudina2902@gmail.com \\ Yuliia Honchar ${ }^{1}$ \\ honchar1992@ukr.net \\ Olena Vasylieva ${ }^{1}$ \\ vasuleva2015@ukr.net \\ Liudmyla Diachuk \\ brousls@ukr.net \\ ${ }^{1}$ Department of Technology and the Organization of Restaurant Business \\ Kyiv National University of Trade and Economics \\ 19 Kyoto str., Kyiv, Ukraine, 02156
}

\begin{abstract}
This study developed a technology of low-lactose semi-finished products, based on fermented whey and pumpkin pulp puree, and offered a possibility of its use in the technology of structured culinary products. This research carried out the required substantiation of the methods of preliminary processing of raw materials, and studied the technological properties and structure of model compositions with their use.

During the experiment, a number of studies were carried out, which substantiated the method and modes of condensation of whey, and provided a comparative analysis of the homogeneity of lactose-free and lactose-containing samples of whey under various modes of condensation.

The study obtained the results of calculations of the equivalent diameter of the studied samples of lactose-containing and low-lactose whey, condensed by the contact method and in vacuum. It was found, that the structure is homogeneous at a number average crystal diameter of up to $5 \mu \mathrm{m}$. The restriction is valid for CLLWV with a calculated diameter of about $3.84 \mu \mathrm{m}$ with a coefficient of variation of $1.35 \%$ with an increase of 10,000 times.

The study revealed the alternation of smooth and granular sections of the micron level $(0.1 \ldots 5 \mu \mathrm{m})$ in the structure of the studied low-lactose semi-finished product with an increase of 300 times. It was determined, that the extremum of the differential curve of the particle size distribution of CLLWV corresponds to the number average crystal diameter of $3.84 \mu \mathrm{m}$. It was established, that the most homogeneous fractional composition is inherent in the studied sample of CLLWV, for which the values of fraction diameters are in the range from $1.46 \mu \mathrm{m}$ to $4.96 \mu \mathrm{m}$. The optimal ratio of the components of the model CLLWV: FPPP system was determined as $70 \%$ to $30 \%$ respectively. With this composition, the model system is characterized by the formation of protein-pectin complexes, which is confirmed by microscopy with a magnification of 90 times.
\end{abstract}

Keywords: condensed low-lactose whey, lactose, model systems, crystallization, microstructure.

DOI: $10.21303 / 2504-5695.2020 .001323$

\section{Introduction}

There is an urgent issue of developing an assortment of lactose-free dairy products for special nutrition of lactose intolerant patients. Scientists have found that the complete exclusion of dairy products in this disease can cause concomitant diseases, associated with a deficiency of $\mathrm{Ca}$, $\mathrm{Mg}$ and vitamin D [1]. To solve this problem, a number of researchers suggest a possibility of complete or partial removal of lactose from dairy raw materials, their further processing and use [2].

Advantageous from this point of view, dairy products are protein-carbohydrate milk raw materials, in particular whey [3]. One of the methods of its processing, which has found practical application, is thickening [4]. The process of condensation of whey may be accompanied by 
crystallization of lactose, which will contribute to the formation of its mealy structure. In order to prevent the crystallization of lactose in dairy products, a method of its enzymatic hydrolysis is used. This method of processing whey also successfully solves the problem of developing low-lactose dairy products. Condensed whey with a reduced content of lactose can be used as a basis for the production of foods or semi-finished products in the diet for patients with lactose intolerance.

Previous studies substantiated the methods and modes of enzymolysis of whey lactose [5] and its thickening [6], the feasibility of it with fermented pumpkin pulp puree (FPPP) [7] in the manufacture of semi-finished products for structured culinary products [8].

\section{Overview of the problem}

The dairy industry produces 75 million tons of whey annually in the European Union, about $40 \%$ of its volume is disposed of. A special program of the European Whey Products Association (EWPA) [9] has been adopted to solve the problem of marketing whey as a by-product of the dairy industry. That is why the processing of secondary milk raw materials, namely whey, is an urgent task. Promising research in this direction and its successful completion will allow developing a number of new effective food technologies.

One way to increase the amount of nutrients in whey is achieved by concentration (freeze drying, thickening, ultrafiltration, etc.) [10]. But it is known, that the quality of food systems is determined by such factors as shape, size and uniformity of the distribution of particles in a dispersed system. Therefore, the characteristics of the microstructure of its components are important in the process of creating a structured culinary product [11].

One of the most important organoleptic characteristics of condensed milk products is their texture. The appearance of texture flaws, in particular mealiness is a consequence of crystallization of lactose [12]. The process of lactose crystallization is characterized by chaotic formation of crystal growth centres as a result of thermalization [13]. During cooling, the number of newly formed crystallization cells increases. As a result, the texture and functional-technological properties of raw materials are changing. A traditional technological solution to this problem is the introduction of fine crystalline lactose as a seeding agent $[14,15]$.

It has been established, that lactose crystallization is affected by its concentration in serum, $\mathrm{pH}$, and the presence of a denatured protein, the degree of supersaturating as a result of thickening, the presence of impurities, the mixing rate, and the cooling rate [16, 17].

Since condensed whey is a polydisperse system, the determination of the size and shape of dispersed particles is important. These parameters determine the properties of disperse systems, and, consequently, the scope of their application [18].

The aim of the article is to study the microstructure and particle size distribution of whey milk whey cheese lactose, depending on the concentration of lactose and methods of thickening, as well as model food systems, based on it.

To achieve this goal, it was necessary to solve a number of problems, namely:

- to determine the characteristics of the microstructure of the samples;

- to establish the nature of the influence of the microstructure on functional and technological properties of model samples;

- to draw conclusions from the obtained data about the influence of technological factors on the microstructure of the samples.

\section{Materials and Methods}

The object of the study was the microstructural characteristics of condensed fermented whey [19], as well as model systems of low-lactose semi-finished product [20, 21], based on it, with the addition of fermented pumpkin pulp puree [22].

The subject of the study at the initial stage was separated milk cheese whey. For the manufacture of sample No. 1, low-lactose whey (hereinafter referred to as CLLWV) was concentrated in vacuum, and for sample No. 2, it was not fermented (hereinafter referred to as CLLWCM). In sample No. 1, the amount of solids is $40 \%$, the lactose content is $2 \%$. 
In sample No. 2 solids are also $40 \%$, while the lactose content is $28 \%$. For the manufacture of sample No. 3, low-lactose whey was concentrated by the contact method (hereinafter - CLLWCM). In sample No. 3 , the solids content is $40 \%$, and the lactose content is $2 \%$. Unfermented whey for sample No. 4 was concentrated by the contact method (hereinafter $-\mathrm{cmWV}$ ). Thickening was carried out until the amount of solids in sample No. 4 reached $40 \%$, with a lactose content of $28 \%$. Anti-crystallizers were not used.

Crystallization uniformity was evaluated by the average crystal diameter. The size of the lactose crystals was determined with the help of microscoping, using a Biolam 70-C11 microscope (Russia), equipped with a simplified illuminator OI-32. The resolution of the optical microscope is $0.1-0.2 \mathrm{mi}-$ crons. The results were recorded by microphotography. The texture was evaluated by optical microscopy, using a bright field, on which in transmitted light it is possible to obtain a uniformly illuminated field in the image plane. The image of the object becomes visible as a result of partial absorption and reflection by its individual elements of the light incident on them. In the process of preparing the analysis, the sample was not heated or diluted in order to prevent the destruction of milk sugar crystals. The preparations were carried out by applying a thin drop of the sample on a glass slide, covered with a coverslip. Studies were conducted in a freshly prepared product and during its storage [23].

The crystallization concentration was calculated by the value of the equivalent crystal diameter per $1 \mathrm{~cm}^{2}$ of the product. The equivalent diameter was determined using the length and width of the particle:

$$
\bar{d}=\frac{(l+b)}{2}
$$

The equivalent diameter is used in connection with the measurement of a large number of particles with their random arrangement and orientation. It was the equivalent diameter that was used to estimate the specific surface area of the particles. The results of the particle size analysis, obtained using microscopy, are expressed by the numerical distribution of particle sizes.

In order to calculate the average particle size, the method of determining the average numerical diameter $\bar{d}_{n}$ was used. The value $\bar{d}_{n}$ corresponds to the particle diameter, of such a monodisperse system, which with the same number of particles has the same sum of diameters as in this dispersed system. Calculations are made according to the formula:

$$
\overline{d_{n}}=\sum_{i} \frac{n_{i}}{\sum_{i} n_{i}} \times d_{i}=\sum_{i} f_{n i} \times d_{i},
$$

where $n_{i}$ - is the number of particles in the i-th fraction (diameter $\left.d_{i}\right) ; \sum_{i} n_{i}$ - total number of particles in the system; $f_{n i}=n_{i} / \sum_{j} n_{j}$ - the numerical fraction of the $i$-th fraction.

Due to the impossibility of calculating the concentration of crystallization in the entire volume of the product, the coefficient of variation was calculated to characterize the degree of polydispersity of the studied system:

$$
K_{n}=\frac{\sigma}{\overline{d_{n}}} \times 100 \%
$$

where $\sigma$ is the standard deviation that characterizes the breadth of particle distribution by the size.

The numerical value of the standard deviation was calculated for the number average diameter, calculated by the formula:

$$
\sigma=\left\{\sum_{i} f_{n i}\left(d_{i}-\overline{d_{n}}\right)^{2}\right\}^{\frac{1}{2}}
$$


Taking into account the calculated values, the granulometric composition of the studied condensed milk whey systems was also determined, which makes it possible to establish the percentage of particles with a certain size range. The percentage of individual fractions is presented in the form of histograms of the studied samples, which is a stepwise graph of the dependence of the relative content of fractions of particles on their size. For a visual representation of the degree of polydispersity of the analyzed systems and the content of each fraction in them, a histogram was built in the form of a diagram, consisting of several rectangles. The number of constructed rectangles corresponds to the number of fractions in the system. The bases of the rectangles are between $d_{i}-\Delta d_{i} / 2$ and $d_{i}+\Delta d_{i} / 2$ diameter values. Due to the equal values of the diameters of intervals in the fractions, the constructed histograms give a visual representation of the degree of polydispersity of the analyzed systems and the content of each fraction in them. When constructing differential particle size distribution curves along the abscissa, the values of their diameters are counted, and along the ordinate, the density of their distribution.

The subject of the study at the second stage was model systems, based on cmWV and pumpkin pulp puree (hereinafter - FPPP) in the given ratios 90:10; 70:30 and 40:60 respectively. The study of the structure of systems was performed at a multiple increase by 90 times.

\section{Experimental procedures}

It is known, that the texture of a condensed milk product depends on the number of lactose crystals and their size. The determination of the size, quantity and nature of the distribution of particles of dispersed systems is of paramount importance since it is these parameters that determine the rheological properties, and as a result, the scope of the system under study. The assessment of the degree of crystallization of lactose is determined by the average size of its crystals in the experimental samples. The degree of crystallization is calculated per $1 \mathrm{~cm}^{2}$ of the sample. According to the calculated numerical values, it is possible to evaluate objectively the structure of the studied samples.

Sample No. 1 (CLLWV) was subjected to preliminary enzymolysis of lactose, followed by concentration in a vacuum at $P=-0.1 \mathrm{~Pa}$ and a reduced boiling point of $50 \pm 2{ }^{\circ} \mathrm{C}$. The gentle processing mode allows to save the colour of the product, prevents coagulation of proteins and the destruction of biologically active substances.

To determine the nature of texture formation of the sample, micrographs were analyzed at a multiple magnification by $\times 10,000$ and $\times 300$ times (Fig. 1, $\boldsymbol{a}, \boldsymbol{b}$ ).

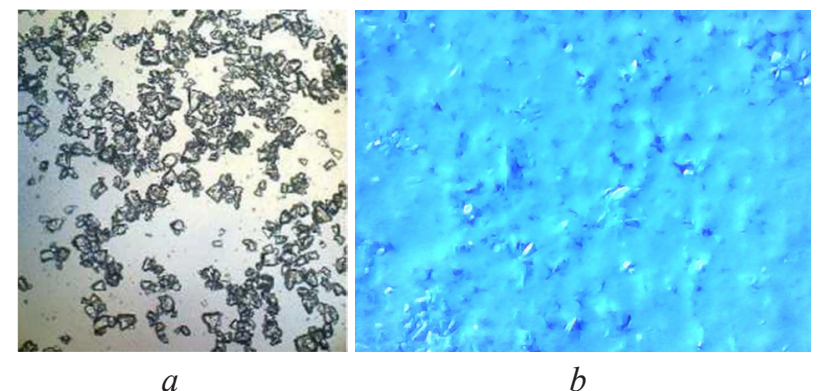

Fig. 1. Sample No. 1 CLLWV with a multiple increase by: $a-\times 10,000$ times; $b-\times 300$ times

The crystallization concentration in $1 \mathrm{~cm}^{2}$ of the product is 450 thousand crystals. The calculated number average crystal diameter is $3.84 \mu \mathrm{m}$ with a coefficient of variation of $1.35 \%$, it characterizes the system as fairly homogeneous since, upon thickening, crystals up to 10 microns in size are formed.

Sample No. 2 (CMWV) was not subjected to preliminary enzymolysis, and, therefore, was characterized by a high lactose content of $5 \%$. The condensation was carried out the same way as for the previous sample, under conditions of weak rarefaction at $\mathrm{P}=-0.1 \mathrm{~Pa}$ at a reduced boiling point.

Microphotography of sample No. 2 was carried out at a multiple magnification by $\times 9000$ and $\times 300$ times (Fig. 2, $\boldsymbol{a}, \boldsymbol{b}$ ), since the sample had a large crystal size in comparison with sample No. 1 . 


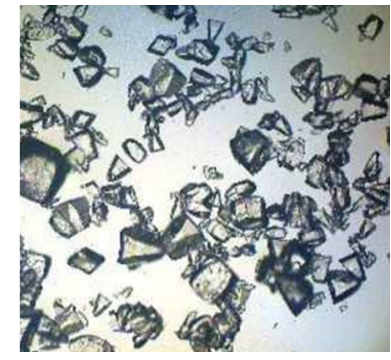

$a$

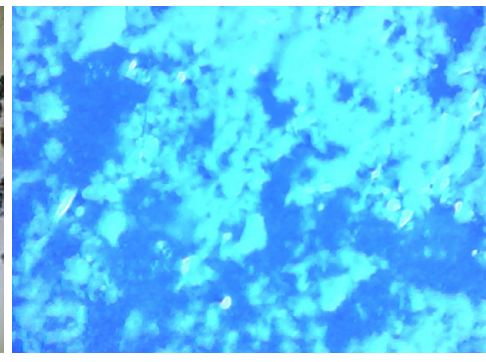

$b$

Fig. 2. Sample No. $2 \mathrm{cmWV}$ with a multiple increase by: $a-\times 9000$ times; $b-\times 300$ times

The crystallization concentration in $1 \mathrm{~cm}^{2}$ of the product is 92 thousand crystals, the calculated value of the number average diameter is 15.54 microns with a coefficient of variation of $5.1 \%$. The system is characterized by a mealy texture, which is confirmed by the calculated values. Mealiness becomes noticeable even when the crystal size is above 11 microns, and negatively affects the texture of the resulting product. Crystal formation continued upon cooling of the sample.

Sample No. 3 (CLLWV) was subjected to preliminary enzymatic hydrolysis of lactose, followed by thickening of low-lactose serum by the contact method with an open evaporation surface. Due to the uneven distribution of temperature in the entire volume of the product and its relatively higher values, melanoid formation was observed, as a result of which the colour of the product changed from white with a touch of green into to saturated creamy colour.

The magnification rate during microphotography of sample No. 3 was $\times 10,000$ and $\times 300$ times (Fig. 3, $\boldsymbol{a}, \boldsymbol{b}$ ), since the low-lactose sample had a smaller comparative crystal size than sample No. 2.

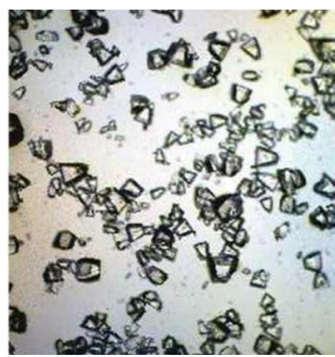

$a$

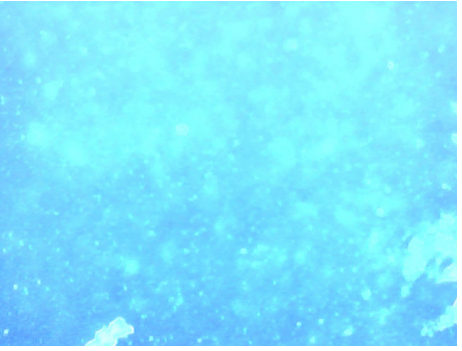

$b$

Fig. 3. Sample No. 3 CLLWCM with a multiple increase by: $a-\times 10,000$ times; $b-\times 300$ times

The crystallization concentration in $1 \mathrm{~cm}^{2}$ of the product is 271 thousand crystals. The calculated number average crystal diameter is $6.7 \mu \mathrm{m}$ with a coefficient of variation of $4.63 \%$. Test sample No. 3 was characterized by mealiness, which become noticeable at a crystal size of 11-30 $\mu \mathrm{m}$. Upon cooling, the crystallization process continued more rapidly.

Sample No. 4 (CLLWV) was not subjected to enzymatic hydrolysis of lactose. The thickening was carried out by the contact method with an open evaporation surface, which caused the product to change color to saturated caramel in the process.

Microphotography of sample No. 4 was performed at a multiple magnification $\times 9000$ and $\times 300$ times (Fig. $4, \boldsymbol{a}, \boldsymbol{b}$ ), since the sample had a larger crystal size in comparison with samples No. 1 and 3.

The crystallization concentration in $1 \mathrm{~cm}^{2}$ of the product is 27 thousand crystals, the calculated value of the number average diameter is $26.15 \mu \mathrm{m}$ with a coefficient of variation of $6.19 \%$. Sample No. 4 , with crystal sizes, bigger than $31 \mu \mathrm{m}$, has a rough sandy texture, which is particularly noticeable.

The analysis of the type of samples at a magnification of x300 times shows that samples No. 1 and No. 3 are distinguished by sufficient uniformity of the structure. Samples No. 2 and No. 4 are characterized by an uneven distribution of dispersed particles and their grouping into complex- 
es. At the micro level, there is an alternation of smooth and granular sections of the micron level $(0.1 \ldots 5 \mu \mathrm{m})$, which probably indicates the high visco-elastic properties of the system. This, in turn, suggests that the resulting food systems are highly reactive and can be used to produce structured food products.
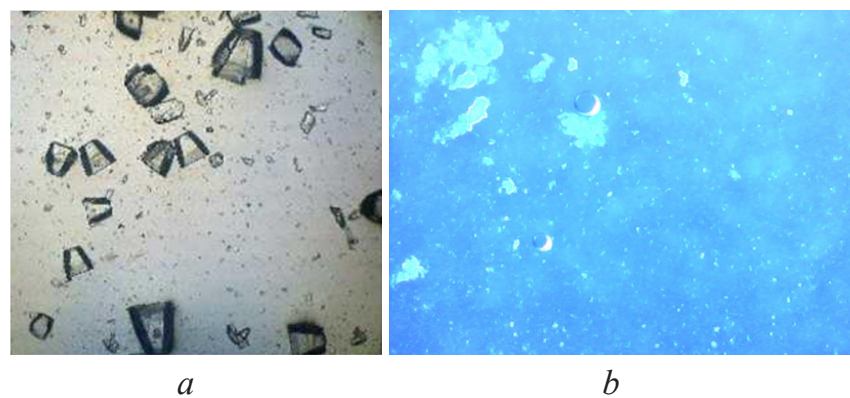

Fig. 4. Sample No. 4 CLLWV with a multiple increase by: $a-\times 9000$ times; $b-\times 300$ times

\section{Discussion of the results}

For the assessment of the degree of crystallization of lactose, it is not enough to conduct a visual description of the structure of the system. Prototypes contain particles, the minimum and maximum sizes of which differ by several times. Therefore, the determination of the average particle size is considered insufficient, and a complete description necessitated the determination of the granulometric composition of lactose crystals in samples of condensed whey (Fig. 5-8). The properties of a disperse system are described by the function of dependence of distribution of the number of crystals on their average size, the numerical values of the crystal distribution density $\left(\frac{\Delta Q_{n}}{\Delta d}, \frac{\%}{\mathrm{mcm}}\right)$ are plotted on the ordinate, and the mean diameters $(\Delta d, \mathrm{mcm})$ are plotted on the abscissa.

In accordance with the calculated data, a histogram of the particle size distribution of sample No. 1 (CMWV) was constructed using a differential curve (Fig. 5).

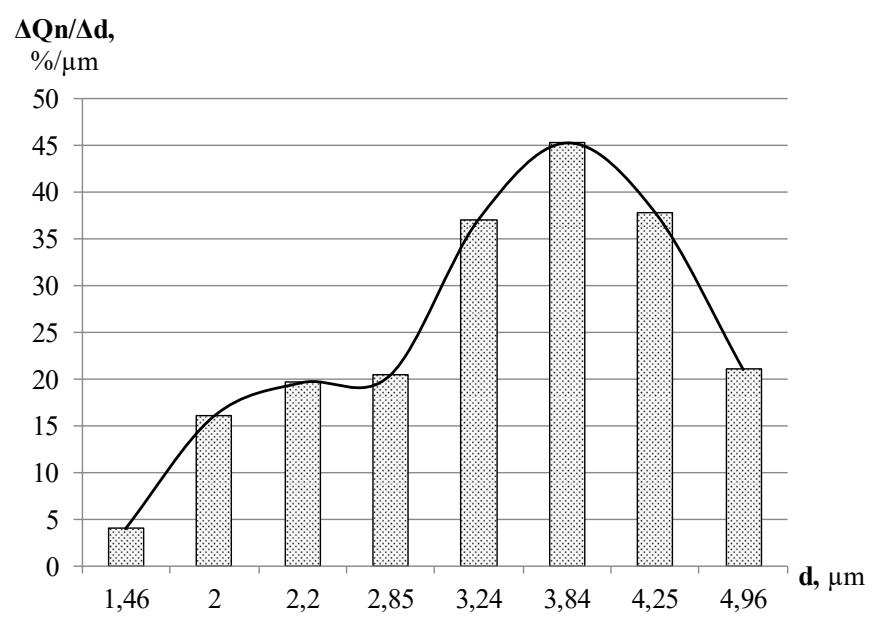

Fig. 5. Granulometric composition of sample No. $1 \mathrm{cmWV}$

Sample No. 1 is characterized by smaller crystals and the smallest range of dimensional values, which indicates a high uniformity of the system.

When considering the particle size distribution of sample No. 2, the differential curve has two peaks in the range of small crystals (Fig. 6).

Sample No. 2, despite the relatively small size range of the lactose crystals, is characterized by a high concentration of particles with a size of 15-20 $\mu \mathrm{m}$. That is, sample No. 2 is lacking mealiness, which is determined by organoleptics. 


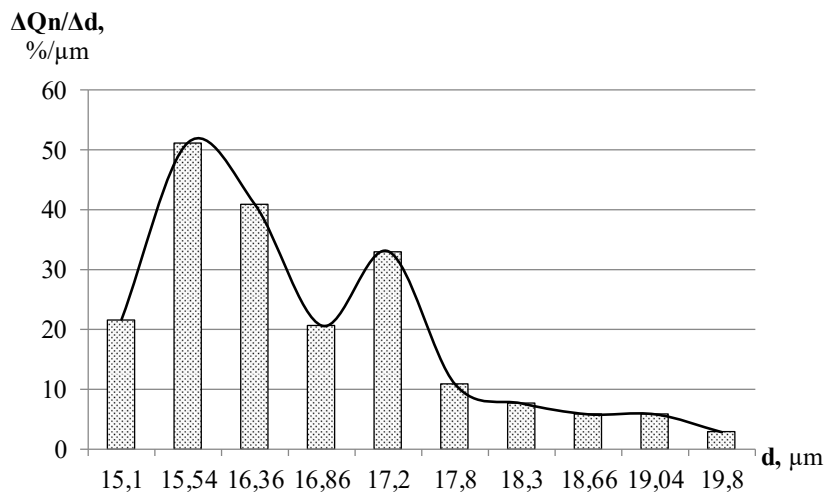

Fig. 6. Granulometric composition of sample No. 2 CLLWV

The granulometric composition of crystals of sample No. 3 is presented in the histogram of Fig. 7 .

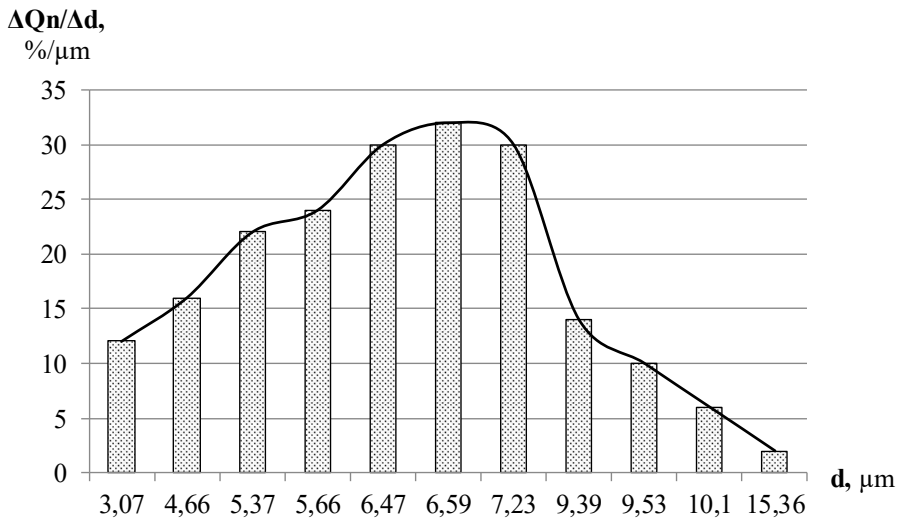

Fig. 7. Granulometric composition of sample No. 3 CLLWV

Sample No. 3 contains a large number of crystals with a diameter of 5-9 $\mu \mathrm{m}$, but at the same time, it is characterized by a high dispersion of particle sizes from 3 to $15 \mu \mathrm{m}$, which give the structure heterogeneity and affect the texture. In addition, because of this dimension, it is difficult to predict the result of interaction with other substances, because lactose particles, depending on size, are characterized with different reactivity.

Based on the data, obtained during the experiment, a histogram of the particle size distribution of the test sample No. 4 was constructed (Fig. 8).

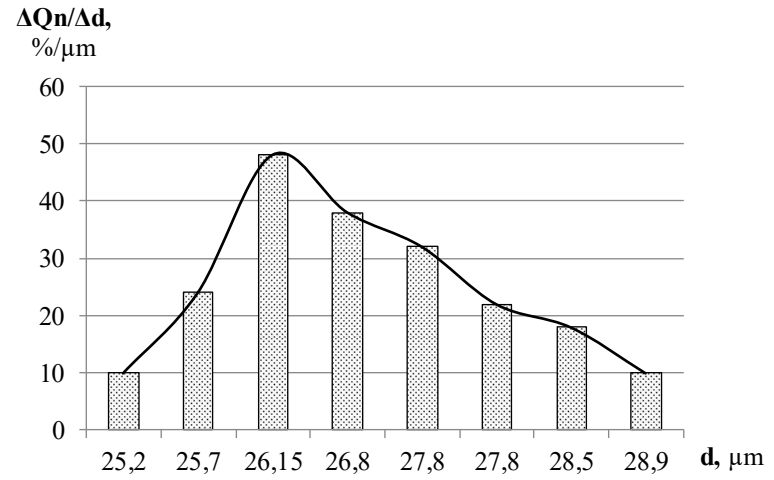

Fig. 8. Granulometric composition of sample No. 4 CLLWCM

Sample No. 4 is characterized by the content of lactose crystals, the average size of which is in the range of $25-28 \mu \mathrm{m}$. This can significantly affect the rheological properties of model systems. 
Accordingly, the only sample that has a uniform texture is sample No. 1 - low-lactose whey, condensed in a vacuum. It can be recommended for use as part of multi-component food systems, as it has good organoleptic characteristics and functional and technological properties.

As it can be seen from Fig. 5-8, with a decrease in the degree of dispersion, the width of the differential distribution curves becomes narrower, and their maximum increases. It is known, that dispersed systems, depending on the particle size distribution, can be restructured in time. This means that during storage under the same conditions, the granulometric composition of the systems can vary, which will manifest itself in the form of clumping, mealiness or sandiness. The particle size distribution of lactose crystals was studied during storage of prototypes for 30 days. The research results are shown in Table 1.

Table 1

Dynamics of changes in the dimensional characteristics of lactose crystals

\begin{tabular}{|c|c|c|c|c|c|}
\hline \multirow{3}{*}{ Sample } & \multirow{3}{*}{$\begin{array}{l}\text { The size of the fraction of } \\
\text { crystals, } \mu \mathrm{m}\end{array}$} & \multicolumn{4}{|c|}{ The numerical content of crystals in $1 \mathrm{~cm}^{2}, \%$} \\
\hline & & \multicolumn{4}{|c|}{ Day } \\
\hline & & 1 & 10 & 20 & 30 \\
\hline \multirow{5}{*}{ No. 1 CLLWV } & $\leq 5$ & 79 & 43 & 37 & 28 \\
\hline & $6-10$ & 21 & 57 & 63 & 65 \\
\hline & $11-15$ & - & - & - & 6 \\
\hline & $16-20$ & - & - & - & 1 \\
\hline & $\geq 25$ & - & - & - & - \\
\hline \multirow{5}{*}{ No. $2 \mathrm{cmWV}$} & $\leq 5$ & 10 & 8 & 5 & 2 \\
\hline & $6-10$ & 78 & 64 & 51 & 42 \\
\hline & $11-15$ & 12 & 28 & 43 & 51 \\
\hline & $16-20$ & - & - & 1 & 4 \\
\hline & $\geq 25$ & - & - & - & 1 \\
\hline \multirow{5}{*}{ No. 3 CLLWCM } & $\leq 5$ & 23 & 20 & 17 & 8 \\
\hline & $6-10$ & 73 & 68 & 59 & 52 \\
\hline & $11-15$ & 5 & 12 & 20 & 30 \\
\hline & $16-20$ & - & - & 4 & 7 \\
\hline & $\geq 25$ & - & - & - & 3 \\
\hline \multirow{5}{*}{ No. 4 CWCM } & $\leq 5$ & 2 & 1 & 1 & - \\
\hline & $6-10$ & 8 & 6 & 5 & 3 \\
\hline & $11-15$ & 18 & 18 & 16 & 13 \\
\hline & $16-20$ & 22 & 20 & 18 & 17 \\
\hline & $\geq 25$ & 50 & 55 & 60 & 67 \\
\hline
\end{tabular}

The results of the research in the dynamics of changes in the dimensional characteristics of lactose crystals, presented in Table 1, showed that lactose crystals in all samples were enlarged, uniting into complexes as a result of consolidation. Already on the 10th day of storage, all samples demonstrated the appearance of crystals of large initial sizes. On day 30, sample No. 1 was characterized by a decrease in the uniformity of the system, while sample No. 4 partially lost fluidity 
due to a significant increase in the crystallization centre. Samples No. 2 and No. 3 were characterized by an increase in the crystallization centre, which contributed to the strengthening of signs of mealiness. The reason for the increase in lactose crystallization after 10 days of storage is the completion of the induction (latent) period, when the lactose concentration remains constant, but the formation of new phase nuclei occurs. At the second stage, a rapid increase in its concentration and crystal growth begins.

For further studies, sample No. 1 was used, which had maximum uniformity in particle size and distribution. The microstructure of model systems was studied, in which CLLWV and fermented pumpkin pulp puree (FPPP) were used in an amount of 10-60 \% (Fig. 9).

The analysis of the structure of the model system with a FPPP content of $10 \%$ (Fig. 9, a) showed that it is characterized by a uniform distribution of protein globules in the protein-vegetable mixture and the absence of protein-pectin complexes. In particular, the microstructure of the sample is predominantly represented by small particles of fiber 3-4 $\mu \mathrm{m}$ wide, and a small amount of isolated particles of rounded shape with a size of $1-1.5 \mu \mathrm{m}$.

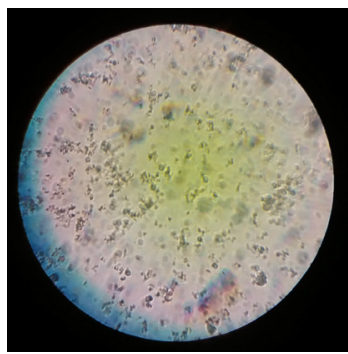

$a$

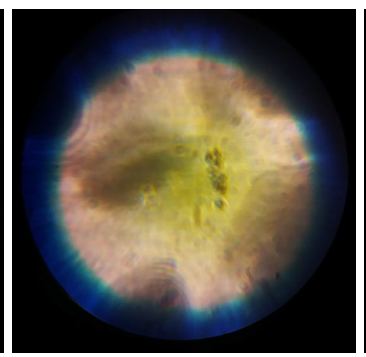

$b$

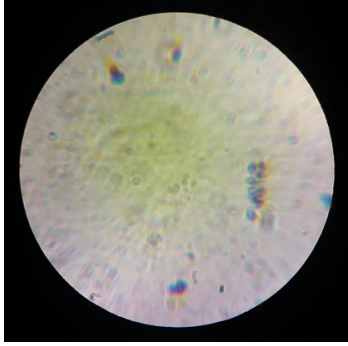

C

Fig. 9. Microstructure of model systems of low-lactose semi-finished product at $23.3^{\circ} \mathrm{C}(90$-fold increase): $a-\mathrm{CLLWV:FPPP=90:10;} b-\mathrm{CLLWV}: \mathrm{FPPP}=70: 30 ; c-\mathrm{CLLWV}: \mathrm{FPPP}=40: 60$

At the same time, the structure of the model system with a FPPP content of $30 \%$ (Fig. 9, b) is characterized by a decrease in the ability to visualize dispersed phases, which is associated with the formation of a more uniform finely-dispersed microstructure and, probably, the formation of elaborated protein-pectin complexes. At the same time, the microstructure of the sample with a FPPP content of $60 \%$ (Fig. 9, ) is represented exclusively by isolated particles of rounded shape with a size of $0.5-1 \mu \mathrm{m}$ of poor visibility without clear contours.

\section{Conclusions}

The results of a number of studies justify the use of condensed low-lactose whey and establish a rational ratio of model systems, using vacuum-condensed low-lactose whey and fermented pumpkin pulp puree.

The information, obtained as a result of the analysis of the microstructure, allows us to state that the pre-fermented low-lactose whey, condensed in a vacuum, has a fairly uniform fine-grained structure. It was established, that the uniformity of the CLLWV structure is achieved due to the prevailing number of number-average-sized crystals of $3.84 \mu \mathrm{m}$ with a fractional composition in the range from $1.46 \mu \mathrm{m}$ to $4.96 \mu \mathrm{m}$. It is proved, that the test sample is characterized by the highest resistance among the samples to crystal formation during storage. Loss of uniformity of CLLWV occurs on the 30th day and is characterized by the appearance of the crystallization centre with a size of $10 \mu \mathrm{m}$ or more. Unlike other samples, this suggests the high technological properties and stability of CLLWV during storage and use.

The research into the structure of model compositions, using vacuum-condensed low-lactose whey and fermented pumpkin pulp puree, established their rational ratio as 70:30. With the established ratio, the formation of a homogeneous fine microstructure is observed, which indicates the presence of protein-pectin complexes. This allows recommending this model system for use in structured production technologies. 


\section{Acknowledgments}

We would also like to express our gratitude for assistance in conducting experiments to Roman Romanenko, Candidate of Technical Sciences, Associate Professor of the Department of Engineering and Technical Disciplines of Kyiv National University of Trade and Economics.

\section{References}

[1] Wilt, T. J., Shaukat, A., Shamliyan, T., Taylor, B. C., MacDonald, R., Tacklind, J. et. al. (2010). Lactose intolerance and health. Evid. Rep. Technol. Assess, 192, 1-410.

[2] Longstreth, G. F., Thompson, W. G., Chey, W. D., Houghton, L. A., Mearin, F., Spiller, R. C. (2006). Functional Bowel Disorders. Gastroenterology, 130 (5), 1480-1491. doi: https://doi.org/10.1053/j.gastro.2005.11.061

[3] DSTU 7170:2010. Dairy industry. Milk and contained milk products. The nomenclature and requirements of titles (2011). Kyiv: Derzhspozhyvstandart Ukrainy, 9.

[4] DSTU 4553:2006. Whey Condensed Unsweetened. Spesifications (2006). Kyiv: Derzhspozhyvstandart Ukrainy, 16.

[5] Gnitsevych, V., Chykun, N., Honchar, Y. (2017). Kinetics of fermentation of lactose whey. Commodities and Markets, $2(24), 97-101$.

[6] Hnitsevych, V. A., Honchar, Yu. M. (2018). Sposib vyrobnytstva zghushchenoi fermentovanoi molochnoi syrovatky zi znyzhenym vmistom laktozy. Materialy Mizhnarodnoi naukovo-praktychnoi konferentsiyi «Rozvytok kharchovykh vyrobnytstv, restorannoho ta hotelnoho hospodarstv i torhivli: problemy, perspektyvy, efektyvnist», 120-121.

[7] Gnitsevych, V., Honchar, Y. (2018). Investigation the process of fermentation of pumpkin pulp. Scientific Works of National University of Food Technologies, 24 (2), 202-208. doi: https://doi.org/10.24263/2225-2924-2018-24-2-24

[8] Gnitsevych, V., Yudina, T., Gonchar, Y. (2018). Technology of semi-finished product based on thickened low-lactose whey and pumpkin pulp. Commodities and Markets, 4, 105-114. doi: https://doi.org/10.31617/tr.knute.2018(28)10

[9] Final Report Summary - WHETLAC (Transformation of the residual whey permeate from the cheese manufacture: lactic acid production). Available at: https://cordis.europa.eu/project/id/222400/reporting

[10] Hramtsov, A. G., Onopriyko, V. A. (2004). Proizvodstvo molochnyh produktov: Tehnologiya molochnyh produktov mini-proizvodstv. Rostov-na-Donu: Izdatel'stvo «Mart», 411.

[11] Golubeva, L. V. (2005). Spravochnik tehnologa molochnogo proizvodstva. Vol. 9. Konservirovanie i sushka moloka. SanktPeterburg: GIORD, 272.

[12] Nasirpour, A., Scher, J., Linder, M., Desobry, S. (2006). Modeling of Lactose Crystallization and Color Changes in Model Infant Foods. Journal of Dairy Science, 89 (7), 2365-2373. doi: https://doi.org/10.3168/jds.s0022-0302(06)72309-8

[13] Arellano, M. P., Aguilera, J. M., Bouchon, P. (2004). Development of a digital video-microscopy technique to study lactose crystallisation kinetics in situ. Carbohydrate Research, 339 (16), 2721-2730. doi: https://doi.org/10.1016/j.carres. 2004.09.009

[14] Garnier, S., Petit, S., Coquerel, G. (2002). Influence of supersaturation and structurally related additives on the crystal growth of $\alpha$-lactose monohydrate. Journal of Crystal Growth, 234 (1), 207-219. doi: https://doi.org/10.1016/s00220248(01)01608-6

[15] Dhumal, R. S., Biradar, S. V., Paradkar, A. R., York, P. (2008). Ultrasound Assisted Engineering of Lactose Crystals. Pharmaceutical Research, 25 (12), 2835-2844. doi: https://doi.org/10.1007/s11095-008-9653-9

[16] McLeod, J., Paterson, A. H. J., Jones, J. R., Bronlund, J. E. (2011). Primary nucleation of alpha-lactose monohydrate: The effect of supersaturation and temperature. International Dairy Journal, 21 (7), 455-461. doi: https://doi.org/10.1016/j. idairyj.2011.01.006

[17] Wong, S. Y., Bund, R. K., Connelly, R. K., Hartel, R. W. (2012). Designing a lactose crystallization process based on dynamic metastable limit. Journal of Food Engineering, 111 (4), 642-654. doi: https://doi.org/10.1016/j.jfoodeng.2012. 03.003

[18] Sinel'nikov, B. M., Hramtsov, A. G., Evdokimov, I. A., Ryabtseva, S. A., Serov, A. V.; Hramtsov, A. G. (Ed.) (2007). Laktoza i ee proizvodnye. Sankt-Peterburg: Professiya, 768.

[19] Hnitsevych, V. A., Honchar, Yu. M., Yevdomakha, T. I. (2019). Pat. No. 136991 UA. Sposib vyrobnytstva napivfabrykatu na osnovi zghushchenoi nyzkolaktoznoi molochnoi syrovatky ta dysperhovanoho piure z miakoti harbuza z pidvysh- 
chenym vmistom pektynu. No. u201902416; declareted: 12.03.2019; published: 25.09.2019, Bul. No. 18. Available at: https://base.uipv.org/searchINV/search.php?action=viewdetails\&IdClaim=261919

[20] TU U 10.8-2860707498-001:2019. Vyrobnytstvo napivfabrykatu na osnovi zghushchenoi nyzkolaktoznoi molochnoi syrovatky ta dysperhovanoho piure z miakoti harbuza z pidvyshchenym vmistom pektynu. DKPP 10.84.12-70.

[21] Hnitsevych, V. A., Honchar, Yu. M. (2018). Pat. No. 129641 UA. Sposib vyrobnytstva fermentovanoi molochnoi syrovatky zi znyzhenym vmistom laktozy. No. u201803960; declareted: 12.04.2018; published: 12.11.2018, Bul. No. 21. Available at: https://base.uipv.org/searchINV/search.php?action=viewdetails\&IdClaim=252564

[22] Hnitsevych, V. A., Honchar, Yu. M. (2018). Pat. No. 129640 UA. Sposib vyrobnytstva fermentovanoho piure z miakoti harbuza z pidvyshchenym vmistom pektynu. No. u201803959; declareted: 12.04.2018; published: 12.11.2018, Bul. No. 21. Available at: https://base.uipv.org/searchINV/search.php?action=viewdetails\&dbname=inv\&lang=ukr\&chapter=biblio\&sortby $=$

[23] Gavrilova, N. N., Nazarov, V. V., Yarovaya, O. V. (2012). Mikroskopicheskie metody opredeleniya razmerov chastits dispersnyh materialov. Moscow: RHTU im. D. I. Mendeleeva, 52.

\title{
INFLUENCE OF ACTIVATED CARBON ON PHYSICAL AND CHEMICAL INDICATORS OF CHEDDAR CHEESE
}

\author{
Marina Samilyk $k^{1}$ \\ m.samilyk@ukr.net \\ Anna Helikh ${ }^{1}$ \\ gelihsumy@gmail.com \\ Natalia Bolgova ${ }^{1}$ \\ bolgova_1981@i.ua \\ ${ }^{1}$ Sumy National Agrarian University \\ 160 Gerasim Kondratyev str., Sumy, Ukraine, 40000
}

\footnotetext{
Abstract

The aim of this research is to substantiate the possibility of using crushed activated carbon (hereinafter referred to as activated carbon) as a food additive in the production of Cheddar cheese in order to expand the range of this type of cheese on the market.

The studied samples of Cheddar cheese, produced in accordance with the technological instructions approved in the prescribed manner, in compliance with the state sanitary regulations for dairy enterprises in accordance with GSP 4.4.4.011.

According to the research results, all physicochemical, microbiological and toxicological indicators comply with the requirements of DSTU 6003:2008.

It is proved that the introduction of activated carbon helps to reduce the amount of moisture without increasing the level of acidity in the finished product. Thus, ensuring the compliance of physico-chemical and microbiological indicators with the requirements of the standard.

In the process of laboratory studies, the presence of carbohydrates in the control and experimental samples is revealed, which indicates the incomplete ripening of cheese in the process of cheddarization. It is established that the introduction of activated carbon during the ripening of cheese helps to reduce the amount of carbohydrates by $2.8 \%$.

The introduction of activated carbon helps to reduce the moisture content by $0.4 \%$, in comparison with the sample without its use. The influence of activated carbon on the indicators of active and triturated acidity, which affect the safety indicators of cheddar cheese during storage for 30 days, is analyzed. As a result of the study, lower $\mathrm{pH}$ values of a sample of cheddar cheese
} 